\title{
Properties of Flour used in Flat Bread (Gaziantep pita) Production
}

\author{
Hatice Pekmez \\ Naci Topçuoğlu Vocational School, University of Gaziantep, 27600 Gaziantep, Turkey \\ E-mail: pekmez@gantep.edu.tr, ORCID: https://orcid.org/0000-0003-3903-469X
}

\begin{tabular}{l|l}
\hline A R T I C L E I N F O & A B S T R A C T \\
\hline Research Article & $\begin{array}{l}\text { Gaziantep pita, one of the regional flat breads in Turkey, had the geographical sign registration } \\
\text { certificate in 2017. Gaziantep pita quality is directly related to flour properties. In present study, } \\
\text { physico-chemical and flourgraph properties of bread flour containing } 0.550 \% \text { and } 0.650 \% \text { ash } \\
\text { content (db.) were investigated. Results showed that the moisture contents of both samples were } \\
\text { not significantly different from each other and were under upper limit of } 14.5 \% \text {. Sedimentation } \\
\text { values for } 0.550 \% \text { and } 0.650 \% \text { ash content (db.) of flours were found good, between } 25-36 \mathrm{~mL} . \\
\text { Wet gluten contents of both flours were determined as medium, between } 20-27 \% \text {. The falling } \\
\text { number values for the samples were higher than normal values. The extensibility values were in } \\
\text { normal values for both flour samples. The resistance to extension values for both samples were } \\
\text { Accepted : }: 05 / 02 / 2019 \\
\text { low, although these values were significantly different from each other. Energy value of } 0.550 \% \\
\text { ash content (db.) of bread flour was in normal value, while energy value of } 0.650 \% \text { ash content } \\
\text { (db.) of flour was low. Physico-chemical and flourgraph properties of } 0.550 \% \text { and } 0.650 \% \text { ash } \\
\text { content (db.) of flours could be improved by blending or adding } \alpha \text {-amylase. }\end{array}$ \\
$\begin{array}{l}\text { Keywords: } \\
\text { Flat bread } \\
\text { Gaziantep pita }\end{array}$ \\
$\begin{array}{l}\text { Pread flour } \\
\text { Physico-chemical }\end{array}$
\end{tabular}

Türk Tarım - Gıda Bilim ve Teknoloji Dergisi 7(2): 209-213, 2019

\section{Pide Ekmeği (Gaziantep pidesi) Yapımında Kullanılan Unun Özellikleri}

\begin{tabular}{|c|c|}
\hline M A K A L E B İ L G İ S İ & Ö Z \\
\hline $\begin{array}{l}\text { Anahtar Kelimeler: } \\
\text { Pide } \\
\text { Gaziantep pidesi } \\
\text { Ekmeklik un } \\
\text { Fiziko-kimyasal } \\
\text { Flourgraf }\end{array}$ & 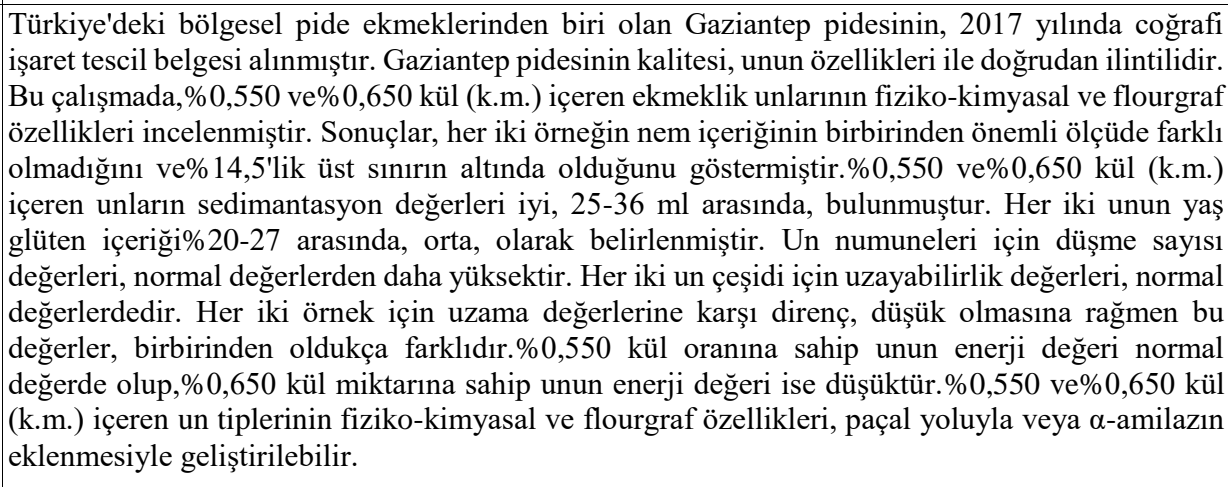 \\
\hline
\end{tabular}

Flourgraf 


\section{Introduction}

Bread has great importance in Turkish cuisine as it is considered as sacred, the symbol of labour and abundance. It is also cheap, satisfying, source of energy and it meets the protein need. Many kinds of breads were produced with grains especially with wheat grown in the Anatolian soil. In general, it has been observed that bread types in each region made with or without yeast were mostly baked in sheet, oven and tandir (Koca and Yazıc1, 2014). One of the most important local breads in the traditional Turkish cuisine is Gaziantep pita which is consumed in almost all urban and rural areas of Southeast Region of Turkey. It is made from white wheat flour and baked in Gaziantep bakeries. In 2017, the geographical sign registration certificate of the Gaziantep pita was awarded to Gaziantep which is among the UNESCO's "Creative Cities Network" in the gastronomy field by Gaziantep Commodity Exchange.

Gaziantep pita which is pertain to Gaziantep, well cooked, distinctive in appearance, smell and colour, is produced by kneading of wheat flour, water, salt and yeast, fermentation of dough, then shaping appropriately and baking in stone or wood ovens. Criteria for Gaziantep pita was determined exactly by Gaziantep Commodity Exchange. Gaziantep pita is a flat bread with a width of about $20 \mathrm{~cm}$, a length of $39 \mathrm{~cm}$ and a thickness of about 1 $\mathrm{cm}$. There is a $1.35 \times 1.40 \mathrm{~cm}$ surface area with generally homogeneous nail spacing due to application special dough shaping technique using by fingertips. Chemical and physical properties of Gaziantep pita are given in Table 1. This table has been prepared by obtaining results from studies done on the pitas taken from three different local producers (Gaziantep Commodity Exchange, 2017).

Flour is the first basic component of bread. In Gaziantep pita making, generally wheat flour with low ash content $(0.550 \%$ and $0.650 \% \mathrm{db}$.) of obtained from bread wheat (Triticum aestivum L.) is preferred and used. The flour used should not contain foreign taste and odor. The moisture content should be $\max 14.5 \%$ and the protein value of the dry substance should be min $10.5 \%$. The acidity in the sulfuric acid type should not exceed $0.07 \%$ (db.). Flour used in Gaziantep pita should be able to absorb high amount of water and should be thicken quickly and easily during kneading. In addition, the dough must be rollen without tearing and provide the desired base and swell (Gaziantep Commodity Exchange, 2017, Turkish food codex, 2013).

In Turkey, flour used in bread making is obtained by milling of many bread wheat varieties like Tosunbey, Seval, Eser, Kenanbey, Gün 91, İkizce 96, Bayraktar 2000, Demir 2000, Zencirci 2002. There are numerous studies on bread wheat varieties and their properties (Aydoğan et al., 2012; 2013, Boros et al., 2009, Boz et al., 2012, Channa et al., 2015, Çağlar et al., 2011, Dikici et al., 2006, Ercan and Seçkin, 1989, Mirahmetoğlu et al., 2007, Ünal et al, 1996). However, there is a limited number of studies for flour used in Gaziantep pita bread (Pekmez, 2018). In present study, the purpose is to investigate the selected properties of bread flour containing $0.550 \%$ and $0.650 \%$ ash (db.), used in Gaziantep pita making.

\section{Materials and method}

Flour Samples

$0.550 \%$ and $0.650 \%$ ash content (db.) of flours produced from bread wheat (Triticum aestivum L.) varieties were used. The wheat flour samples were obtained as additive free from commercial miller in Gaziantep, Turkey.

\section{Physico-chemical Analysis}

Moisture contents were determined according to American Association of Cereal Chemists-approved methods 44-15A (AACC, 2000). Wet gluten contents were determined according to International Association for Cereal Science and Technology standard method 137-1 (ICC, 2012) using the Glutomatic 2200 system (Perten, Huddinge, Sweden). Falling number values and Zeleny sedimentation volumes were determined according to AACC method 56-81B and 56-60 (AACC, 2000). All determinations were carried out in duplicate.

\section{Rheological Analysis}

Extensibility in mm, maximum resistance to extension in HE (Haubelt Einheit) and energy in $\mathrm{cm}^{2}$ of the dough were determined using an flourgraph (Haubelt Flourgraph E7, Duisburg, Germany) according to International Association for Cereal Science and Technology standard method 180 (ICC, 2012). Dough extension values were obtained and evaluated according to the curves after 45, 90 and $135 \mathrm{~min}$ of dough proofing. All determinations were carried out in duplicate.

\section{Statistical Analysis}

The data were statistically analysed by analysis of variance (ANOVA) using Statgraph software (Statgraph, 1991). The least significant differences (LSD) were calculated with the same software.

\section{Results and discussion}

\section{Physico- chemical Properties}

The results for some physico-chemical characteristics of $0.550 \%$ and $0.650 \%$ ash content (db.) of bread flour used in Gaziantep pita are shown in Table 2. The results in Table 2 represent $0.550 \%$ and $0.650 \%$ ash content (db.) of flour containing moisture, $14.3 \%$ and $14.1 \%$. The moisture contents of both samples were not significantly different from each other $(\mathrm{P}>0.0 .5)$. The moisture content of flour is important for commercially and storage. As high moisture content of flour reduces in dry matter, it also causes a decrease in commercial value. Germination of bacterial and fungal activities is promoted by high moisture content which makes the storage of flour difficult (Elgün et al., 1999). High moisture content also enhances the proteolytic and lipolytic activities leading to loss of nutrients (Channa et al., 2015). The moisture content should be $\max 14.5 \%$ according to Turkish food codex (2013). In present study, moisture contents of both $0.550 \%$ and $0.650 \%$ ash content (db.) of flours were under the upper limit and determined as suitable for flour used in Gaziantep pita making. 
Table 1 Chemical and physical properties of Gaziantep pita (Gaziantep Commodity Exchange, 2017)

\begin{tabular}{l|lr}
\hline \multicolumn{1}{c|}{ Property } & & Value \\
\hline Weight $(\mathrm{g})$ & & $175.0-200.0$ \\
Width $(\mathrm{cm})$ & & $20.0 \pm 2.0$ \\
Length $(\mathrm{cm})$ & & $39.0 \pm 2.0$ \\
Thickness $(\mathrm{cm})$ & & $0.75-1.30$ \\
\hline \multirow{2}{*}{ Nail space } & width $(\mathrm{cm})$ & $1.35 \pm 0.10$ \\
& length $(\mathrm{cm})$ & $1.45 \pm 0.15$ \\
\hline & $\mathrm{L}^{*}$ & $55.01 \pm 0.90$ \\
Upper surface colour & $\mathrm{a}^{*}$ & $5.63 \pm 0.40$ \\
& $\mathrm{~b}^{*}$ & $22.74 \pm 0.20$ \\
& $\mathrm{YI}^{*}$ & $61.10 \pm 0.60$ \\
\hline & $\mathrm{L}^{*}$ & $72.64 \pm 0.40$ \\
Lower surface colour & $\mathrm{a}^{*}$ & $1.79 \pm 0.10$ \\
& $\mathrm{~b}^{*}$ & $19.35 \pm 0.60$ \\
& $\mathrm{YI}^{*}$ & $41.96 \pm 0.70$ \\
\hline Moisture $(\%)$ & & $34.17 \pm 0.97$ \\
Protein $(\mathrm{db} \%)$ & & $12.68 \pm 0.25$ \\
Salt (db\%, max) & & 1.50 \\
\hline
\end{tabular}

Table 2 Results of physico-chemical analyses on $0.550 \%$ and $0.650 \%$ ash content (db.) of bread flour. Results are average of duplicate measurements $\pm \mathrm{sd}$.

\begin{tabular}{l|cc}
\hline \multicolumn{1}{c|}{ Analyses } & $0.550 \%$ ash content (db.) of flour & $0.650 \%$ ash content (db.) of flour \\
\hline Moisture content $(\%)$ & $14.3 \pm 0.6^{\mathrm{a}}$ & $14.1 \pm 0.6^{\mathrm{a}}$ \\
Sedimentation volume (mL) & $34.5 \pm 0.9^{\mathrm{a}}$ & $32.2 \pm 0.4^{\mathrm{a}}$ \\
Wet gluten (\%) & $24.5 \pm 0.6^{\mathrm{a}}$ & $25.2 \pm 0.5^{\mathrm{a}}$ \\
Falling number (s) & $278 \pm 7^{\mathrm{a}}$ & $280 \pm 8^{\mathrm{a}}$ \\
\hline
\end{tabular}

Means with the same letter within a row are not significantly different $(\mathrm{P}=0.05)$ by $\mathrm{LSD}$, sd.: standard deviation.

Table 3 Flourgraph results of $0.550 \%$ and $0.650 \%$ ash content (db.) of bread flour. Results are average of duplicate measurements \pm sd.

\begin{tabular}{|c|c|c|}
\hline Flourgraph values & $0.550 \%$ ash content (db.) of flour & $0.650 \%$ ash content (db.) of flour \\
\hline \multicolumn{3}{|c|}{ Extensibility $(\mathrm{mm})$} \\
\hline 45. $\min$ & $159 \pm 5^{\mathrm{a}}$ & $165 \pm 6^{\mathrm{a}}$ \\
\hline 90. $\min$ & $138 \pm 7^{\mathrm{a}}$ & $138 \pm 5^{\mathrm{a}}$ \\
\hline 135. min & $140 \pm 6^{\mathrm{a}}$ & $139 \pm 5^{\mathrm{a}}$ \\
\hline \multicolumn{3}{|c|}{ Resistance to extension (HE) } \\
\hline 45. $\min$ & $290 \pm 6^{\mathrm{a}}$ & $225 \pm 8^{b}$ \\
\hline 90. $\min$ & $361 \pm 9^{a}$ & $270 \pm 5^{b}$ \\
\hline 135. min & $349 \pm 10^{\mathrm{a}}$ & $247 \pm 5^{\mathrm{b}}$ \\
\hline \multicolumn{3}{|c|}{ Energy $\left(\mathrm{cm}^{2}\right)$} \\
\hline 45. $\min$ & $90 \pm 6^{\mathrm{a}}$ & $72 \pm 4^{b}$ \\
\hline 90. $\min$ & $84 \pm 7^{\mathrm{a}}$ & $65 \pm 2^{b}$ \\
\hline 135. $\min$ & $84 \pm 6^{\mathrm{a}}$ & $57 \pm 3^{\mathrm{b}}$ \\
\hline
\end{tabular}

Means with the same letter within a row are not significantly different $(P=0.05)$ by LSD, sd.: standard deviation.

Sedimentation volumes of flour for Gaziantep pita making are shown in Table 2. The sedimentation values were $34.5 \mathrm{~mL}$ for $0.550 \%$ ash content (db.) of flour and $32.2 \mathrm{~mL}$ for $0.650 \%$ ash content (db.) of flour. The sedimentation values were not significantly different from each other $(\mathrm{P}>0.0 .5)$. Zeleny sedimentation test was used to measure the total amount of gluten in wheat flour, hence its quality for bread making can be revealed (Zeleny, 1947), as the protein showed positive correlations with dry gluten and in tune with Zeleny values (Noorka et al., 2009). Sedimentation value is used to predict the quantity and quality of gluten, as well as to estimate the protein content of wheat with the same gluten quality. High sedimentation value indicates that the gluten has good water holding capacity and the bread has high volume (Elgün et al 2001). With high levels of gluten-containing flours, the sedimentation rate is high when the gluten quality is high (Elgün et al. 1999). Zeleny sedimentation value for bread wheat is good above $36 \mathrm{~mL}$, good between $25-36 \mathrm{~mL}$, poor between 16-24 mL and poor below $15 \mathrm{~mL}$ (MEB, 2013). In present study, sedimentation values for $0.550 \%$ and $0.650 \%$ ash content (db.) of flours were found good according to values of MEB (2013). The sedimentation values for both flour samples studied in this research were suitable to use as flour in Gaziantep pita.

Wet gluten contents of flour samples used as the materials of present study are represented in Table 2 . The values were found $24.5 \%$ for $0.550 \%$ ash content (db.) of flour and $25.2 \%$ for $0.650 \%$ ash content (db.) of flour. Wet gluten content of $0.550 \%$ ash content (db.) of flour was not significantly different from wet gluten of $0.650 \%$ ash content (db.) of flour $(\mathrm{P}>0.0 .5)$. Gluten, an important 
indicator of the bread quality of wheat, is elastic protein showing the suitability of flour for bread making. During the dough kneading, it forms a net-like structure, allowing the $\mathrm{CO}_{2}$ produced by the yeast to be retained during fermentation and to form large volume breads. The high level of wet gluten is an indication of good quality bread. Wet gluten content refers to the amount and properties of gluten found in the protein content (Çağlar et al., 2011). Uluöz (1965) defined the gluten content as high, if it is above $27 \%$, as medium if it is between $20-27 \%$ and as low if it is below $20 \%$. In present study, wet gluten contents of both flour samples were found as medium, because they were between $20-27 \%$. Wet gluten contents of flour samples used in this study were found acceptable for Gaziantep pita making.

Falling numbers of flour samples were shown in Table 2. Falling numbers for $0.550 \%$ and $0.650 \%$ ash content (db.) of flours were $278 \mathrm{~s}$ and $280 \mathrm{~s}$, not significantly different $(\mathrm{P}>0.05)$. Falling number is an indication of $\alpha$ amylase activity in flour (Köksel et al., 2000). The deficiency of $\alpha$-amylase in flour can result in problems in the breads produced (Hoseney, 1994). Falling number is a parameter used in determination of diastatic activity in wheat flour and it is important for the amount of gas to be produced in bread making, bread volume, bread texture and bread colour. It is desirable that the number of drops is not high as an indication of normal enzyme activity in wheat cultivars. The duration of wheat starch under saturation and loss of viscosity by the activity of amylase enzymes gives the number of drops in seconds (Ünal, 2002). It is desirable that falling number in wheat be between 220 and $250 \mathrm{~s}$ (Bulut, 2012). In present study, the results showed that the falling number values for both flour samples were higher than normal values. This means that diastatic activity in wheat flour samples were not enough to make bread. Ünal (2002) states that if the falling number is higher than the acceptable limits, the flour is not able to form enough gas and the bread is tight, as the enzyme content is not added to the flour. For this reason, flour, which is not suitable for falling, needs to be improved by blending. Flour used in Gaziantep pita which is a flat type of bread, has lower $\alpha$ amylase activity than the flour for loaf of bread types has. So they could be improved by adding $\alpha$-amylase and/ or blending with the wheat flours having higher $\alpha$-amylase activity as the fermentation period is shorter in Gaziantep pita making.

\section{Rheological Properties by Flourgraph}

Flourgraph results of bread flour $0.550 \%$ and $0.650 \%$ ash content (db.) of flour are shown in Table 3. Flourgraph extensibility values of $0.550 \%$ and $0.650 \%$ ash content (db.) of flours were 159 and $165 \mathrm{~mm}$ at 45 . min, 138 and $138 \mathrm{~mm}$ at 90 . min, 140 and $139 \mathrm{~mm}$ at 135 . min. Extensibility values of flour samples were not significantly different from each other $(\mathrm{P}>0.0 .5)$. The resistances of $0.550 \%$ and $0.650 \%$ ash content (db.) of flours were 290 and $225 \mathrm{HE}$ at 45 . min, 361 and $270 \mathrm{HE}$ at 90. min, 349 and $247 \mathrm{HE}$ at 135 . min. The resistance to extension values for $0.550 \%$ ash content (db.) of flour were significantly different from values for $0.650 \%$ ash content (db.) flour $(\mathrm{P} \leq 0.0 .5)$. Energy value ranges of $0.550 \%$ and $0.650 \%$ ash content $\left(\mathrm{db}\right.$.) of flours were 90 and $72 \mathrm{~cm}^{2}$ at 45 . min, 84 and $65 \mathrm{~cm}^{2}$ at 90 . min, 84 and $57 \mathrm{~cm}^{2}$ at 135 . min. Energy values for both samples were significantly different from each other $(\mathrm{P} \leq 0.0 .5)$.

The extensograph has proved useful in the classification and assessment of flours on the basis of physical dough properties (in particular, flour strength) for both quality control and applied and basic research application (Boros et al., 2009). In the study of Iancu et al. (2010), the Brabender Extensograph and Haubelt Flourgraph E7 were compared and they demonstrated that the equipment used can give values that similarly characterize the behaviour of dough, if the same method of determination is used. Dough extensibility and resistance to extension are widely used in determining the differences between the qualities of bread flour and in selecting suitable raw materials. Extensibility and dough strength (resistance) from rheological properties are used to determine the ability of wheat to be processed into different crops. Extensibility is one of the keys to grain chemistry as it provides important information about cooking performance and final product quality (Anderssen et al., 2004). In addition, it is stated that during fermentation by extensibility test, changes in the dough during fermentation can be determined and very important information about the process can be obtained (Dogan et al., 1996). The maximum resistance value affecting the final product quality is significantly affected by the protein content of the flour. As in the case for extensibility, the increase in protein content of the flour also increases this value (Aydoğan et al., 2013).

Extensibility value for bread wheat flour is evaluated as high if it is $151 \mathrm{~mm}$ and higher value, as normal if it is between 130-150 mm and as low if it is $129 \mathrm{~mm}$ and lower value. Resistance to extension of dough is high if it is 601 BU (Brabender unit) or HE (Haubelt Einheit) and higher, normal if it is between 400 and $600 \mathrm{BU}$ and low if it is 399 BU and lower. Energy value for dough is accepted as high if it is higher than $121 \mathrm{~cm}^{2}$ and higher, as normal if it is between $80-120 \mathrm{~cm}^{2}$ and as low if it is $79 \mathrm{~cm}^{2}$ and lower value (MEB, 2013). According to this evaluation, the extensibility values were normal for $0.550 \%$ and $0.650 \%$ ash content (db.) of flours. The resistance to extension values for both samples were low, although these values were significantly different from each other $(\mathrm{P} \leq 0.0 .5)$. Energy value range of $0.550 \%$ ash content (db..) of flour was in normal value, while energy value of $0.650 \%$ ash content (db.) flour was low. In practice, high extensibility, low resistance to extension and low energy are desired by Gaziantep bakers for easy dough processing and special shaping due to shorter fermentation time.

\section{Conclusions}

In present study, moisture contents of flours with $0.550 \%$ and $0.650 \%$ ash content (db.) were under upper limit of $14.5 \%$. Sedimentation values were found well, between 25-36 mL. Wet gluten contents were determined as medium, between $20-27 \%$. The falling number values for the samples were higher than normal values. The extensibility values were in normal values, while the resistance to extension values were low. Energy value of $0.550 \%$ ash content of bread flour was in normal value, while energy value of $0.650 \%$ ash content of flour was low. It was concluded that physico-chemical and extensibility 
properties of bread wheat (Triticum aestivum L.) flour containing $0.550 \%$ and $0.650 \%$ ash content (db.) investigated in this research were generally convenient acceptable to use in Gaziantep pita making. However, they could be improved by adding $\alpha$-amylase to make the flour stronger and hence Gaziantep pita more attractive as a final product.

\section{References}

AACC. 2000. American Association of Cereal Chemists Approved Methods of the American Association of Cereal Chemists, $10^{\text {th }}$ ed. Method 44-15A. AACC, St Paul, MN, USA.

Anderssen RS, Bekes F, Gras PW, Nikolov A, Wood JT 2004. Wheat-flour dough extensibility as adiscriminator for wheat varieties. J. Cereal Sci. 39: 195-203.

Aydoğan S, Göçmen Akçacık A, Şahin M, Kaya Y, Koç H, Görgülü MN, Ekici M 2012. Determination of the relations between rheological properties of wheat flour which measured with alveograph, farinograph and mixograph. J. Süleyman Demirel Uni. Fac. Agric. 7 (1): 74-82.

Aydoğan S, Göçmen Akçacık A, Şahin M, Önmez H, Demir B, Yakışır E 2013. Determination of physicochemical and rheological properties of bread wheat varieties. J. Field Crop Cent. Res. Ins. 22 (2): 74-85.

Boros N, Tarján Z, Mars E, Borbély M, Győri Z 2009. Comparison of alveograph and extensigraph properties of winter wheat samples. Agrártudományı Közlemények. 36: 27-30.

Boz H, Gerçekaslan KE, Karaoğlu MM, Kotancılar HG 2012. Differences in some physical and chemical properties of wheat grains from different parts within the spike. Turk. J. Agric. For. 36: 309-316.

Bulut S 2012. Quality in bread wheat. J. Erciyes Üni. Ins. Sci. Tech. 28 (5): 441-446.

Channa MJ, Ghangro AB, Sheikh SA, Nizamani SM 2015. Physico-chemical characteristics and rheolgical properties of different wheat varieties grown in Sindh. Pak. J. Anal. Environ. Chem. 16 (2): 11-18.

Çağlar Ö, Karaoğlu MM, Bulut S, Kotancılar HG, Öztürk A 2011. Determination of some quality characteristics in winter facultative bread wheat (Triticum aestivum L.) varieties. J. Animal Veter. Adv. 10 (Suppl.): 3356-3362.

Dikici N, Bilgiçli N, Elgün A, Ertaş N 2006. A research on determination of the relationship between baking quality of flour dough rheologic properties measured with different methods. Food. 31 (5): 285-291.

Dogan İS, Ponte JG, Walker CE 1996. Effect of formula and process variations on Turkish francala bread production. Cereal Foods World. 41 (9):741

Elgün A, Ertuğay Z, Certel M, Kotancılar HG 1999. Guide book for analytical quality control and laboratory for cereal and cereal products. Atatürk Uni. Press, Erzurum, Turkey.

Elgün A, Türker S, Bilgiçli N 2001. Tahıl ve ürünlerinde analitik kalite kontrolü. Selçuk Üni. Fac. Agric. Food Eng. Press, $2^{\text {nd }}$ ed. Konya, Turkey.

Ercan R, Seçkin R 1989. Ülkemizde yetiştirilen yabancı ekmeklik buğday çeşitlerinin kalitesi. Food. 14 (6): 353-361.
Erekul O, Kautz T, Ellmer F, Turgut İ 2009. Yield and bread making quality of different wheat (Triticum aestivum L.) geneotypes grown in Western Turkey. Arch. Agronomy Soil Sci. 55 (2): 169-182.

GTB. 2017. Gaziantep Commodity Exchange The geographical sign registration certificate for Antep Trrnaklı Pidesi (Gaziantep pita), No: 223, Gaziantep, Turkey.

Hoseney RC 1994. Principles of cereal science and technology. Pp. 91-94. Minnesota, USA: The American Association of Cereal Chemists.

Iancu ML, Ognean M, Haubelt G, Jâşcanu V 2010. Dough rheological properties of brown flour type 1250 with additives, studied with the Haubelt flourgraph E7 and Brabender Extensograph. Acta Universitatis Cibiniensis Series E: Food Tech. 14 (1): 3-11.

ICC. 2012. International Associations for Cereal Science and Technology. The Standard Methods of the ICC, 2012 ed. ICC Standard No. 180, Approved 2012. ICC, Vienna, Austria.

International Association of Cereal Chemistry (IACC) 1972. International Association of Cereal Chemistry Standard No. 115-116. IACC, St Paul, MN, USA.

Koca N, Yazıcı H 2014. Coğrafi faktörlerin Türkiye ekmek kültürü üzerindeki etkileri. Int. Period. Lang. Lit. Hist. Turk. 9 (8): 35-45.

Köksel H, Sivri D, Özboy Ö, Basman A, Karacan H 2000. Hububat Laboratuvarı El Kitab1, pp. 42-45. Ankara, Turkey: Hacettepe University Press.

Ministry of Education (MEB) 2013. Module of analyses for bakery products 2 . Food Technology, Ankara, Turkey.

Mirahmetoğlu D, Doğan İ, Meral R 2007. Van ilindeki un fabrikalarının değerlendirilmesi. Elect. J. Food Tech. 1: 2533.

Noorka IR, Rehman S, Haidry JR, Khaliq I, Tabassum S, Mueenud-Din G 2009. Effect of water stress on physico-chemical properties of wheat (Triticum aestivum L.). Pak. J. Bot. 41 (6): 2917-2924.

Özturk A, Çaglar O, Bulut S 2006. Growth and yield response of facultative wheat to winter sowing, freezing sowing and spring sowing at different seeding rates. J. Argon. Crop Sci. 192: 10-16.

Pekmez, H 2018. Physicochemical characteristics and flourgraph properties of wheat varieties (Triticum aestivum L.) used in flat bread (Gaziantep pita). CyTA- J. Food. 16 (1): 965-971.

Statgraph 1991. User's Guide to Statgraph, pp. 345-346. New York, USA: Statistical Graphics Corporation.

Tayyar S 2005. Determination of yield and some quality charcteristics of different bread wheat (Triticum aestivum L.) varieties and lines grown in Biga. J. Akdeniz Üni. Agric. Fac. 18: 405-409.

Turkish food codex 2013. Wheat flour communique, no: 2013/9, Official gazette, 28606.

Uluöz M 1965. Wheat, flour and bread analysis methods. Ege Üni. Press, İzmir, Turkey.

Ünal S 2002. Importance of wheat quality and methods in wheat quality determination. In: Proceedings of the Cereal Prod. Tech. Congress, October 3-4, Gaziantep, Turkey, pp 25-37.

Ünal S, Olçay M, Özer Ç 1996. A study on the quality characteristics of some bread wheat varieties. Food. 21 (6): 451-456.

Zeleny L 1947. A simple sedimentation test for estimating the bread-baking and glüten qualities of wheat flour. Cereal Chem. 24: 465-475. 